\title{
Effect of biochar amendment on nitrate retention in a silty clay loam soil
}

\author{
Angela Libutti, Massimo Mucci, Matteo Francavilla, Massimo Monteleone \\ Star AgroEnergy Research Unit, Department of Science of Agriculture, Food and Environment, \\ University of Foggia, Foggia, Italy
}

\begin{abstract}
Biochar incorporation into agricultural soils has been proposed as a strategy to decrease nutrient leaching. The present study was designed to assess the effect of biochar on nitrate retention in a silty clay loam soil. Biochar obtained from the pyrogasification of fir wood chips was applied to soil and tested in a range of laboratory sorption experiments. Four soil treatments were considered: soil only (control), soil with 2,4 and $8 \%$ of biochar by mass. The Freundlich sorption isotherm model was used to fit the adsorbed amount of nitrate in the soil-biochar mixtures. The model performed very well in interpreting the experimental data according to a general linear regression (analysis of co-variance) statistical approach. Nitrate retention in the soilbiochar mixtures was always higher than control, regardless the $\mathrm{NO}_{3}{ }^{-}$ concentration in the range of $0-400 \mathrm{mg} \mathrm{L}^{-1}$. Different sorption capacities and intensities were detected depending on the biochar application rate. The highest adsorption capacity was observed in the soils added with 2 and $4 \%$ of biochar, respectively. From the results obtained is possible to infer that nitrate retention is higher at lower biochar addition rate to soil (2 and 4\%) and at lower nitrate concentration in the soil water solution. These preliminary laboratory results suggest that biochar addition to a typical Mediterranean agricultural soil could be an effective management option to mitigate nitrate leaching.
\end{abstract}

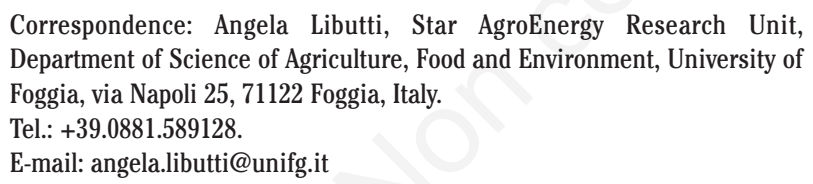

Key words: Biochar; Freundlich sorption model; groundwater quality; nitrate leaching; nutrients retention.

Conflict of interest: the authors declare no potential conflict of interest.

Conference presentation: SIA XLIV Congress, Bologna, 2015.

Received for publication: 1 February 2016.

Revision received: 19 April 2016.

Accepted for publication: 2 May 2016

(C) Copyright A. Libutti et al., 2016

Licensee PAGEPress, Italy

Italian Journal of Agronomy 2016; 11:780

doi:10.4081/ija.2016.780

This article is distributed under the terms of the Creative Commons Attribution Noncommercial License (by-nc 4.0) which permits any noncommercial use, distribution, and reproduction in any medium, provided the original author(s) and source are credited.

\section{Introduction}

Large fertilising applications in intensive cropping systems are the main cause of nutrient loss from agricultural soils to aquatic systems (Yao et al., 2012). Among these nutrients, nitrogen is of prime concern. Nitrogen in the form of nitrate $\left(\mathrm{NO}_{3}{ }^{-}\right)$is highly soluble within the soil water solution, poorly adsorbed by the soil particles and therefore prone to be leached away by the water percolating along the soil profile. $\mathrm{NO}_{3}{ }^{-}$leaching depletes soil fertility, limits the nitrogen utilisation efficiency by the plants, reduces crop yields and represents a significant economic cost for farmers. Moreover, adverse impacts on environmental and human health might be developed by nitrate leaching. It is therefore very important to develop effective technical solution able to mitigate nitrate leaching from agricultural fields. Increasing the $\mathrm{NO}_{3}{ }^{-}$retention capacity of soil has the potential to reduce nitrate losses and improve nitrogen utilisation efficiency for a sustainable crop production. On this respect, the use of biochar is currently raising interest as a potential means to increase the capacity of soils to retain nutrients (Atkinson, 2010). Biochar is the solid, carbonaceous product obtained by the thermochemical processes (pyrolysis or gasification) of biomass conversion into renewable energy products (Laird et al., 2009). The use of biochar as soil amendment has gained attention as a valid strategy to mitigate global climate change, by sequestering atmospheric $\mathrm{CO}_{2}$ and reducing greenhouse gas emissions (Laird, 2008), improve physicochemical and microbiological soil properties (Gul et al., 2015), enhance plant growth and crop yield (Vaccari et al., 2011). What is specifically relevant to our study is that biochar seems to have the potential to reduce $\mathrm{NO}_{3}{ }^{-}$leaching (Knowles et al., 2011). Mechanism of decreased nitrate leaching were found to be the adsorption of $\mathrm{NO}_{3}{ }^{-}$on anion exchange surface of biochar, particularly when biochar was obtained at high temperatures $\left(>600^{\circ} \mathrm{C}\right)$; the inhibited nitrification and thus the decreased nitrate production; the $\mathrm{N}$ immobilisation due to the presence of labile $\mathrm{C}$ in biochar; the incorporation of $\mathrm{NO}_{3}{ }^{-}$present in soil solution into biochar pores; the increased water retention in the soil which may reduce $\mathrm{NO}_{3}{ }^{-}$leaching (Lone et al., 2015). Recently, a number of studies, carried out in open field (Ventura et al., 2013), in pots experiment (Buecker et al., 2016) or using columns leaching (Bradley et al., 2015; Kanthle et al., 2016; Yuan et al., 2016), indicated that biochar is an effective option of nitrate leaching mitigation. However, other studies oppositely showed a limited or no ability of biochar to retain $\mathrm{NO}_{3}{ }^{-}$. Yao et al. (2012) found the poor ability of nine out of thirteen biochars tested to adsorb nitrate. Hollister et al. (2013), in sorption experiments carried out using biochar from corn or oak, observed the inability of biochar to retain $\mathrm{NO}_{3}{ }^{-}$. Eykelbosh et al. (2015) found that biochar from sugarcane filtercake did not lessen $\mathrm{NO}_{3}{ }^{-}$leaching from the soil. These contradictory results are likely because of the differences in type of biochar, type of soil and level of biochar applied. Therefore, the nitrate sorption effectiveness of biochar need to be studied prior to its application aimed at controlling nitrogen losses from agricultural soil.

In this study, we investigated the effect of fir wood biochar applica- 
tion on nitrate retention in a silty clay loam soil. A range of laboratory experiments was carried out with the aim to assess whether soil amendment with several amounts of biochar can affect the ability to retain $\mathrm{NO}_{3}{ }^{-}$and, eventually, the most effective biochar application rate.

\section{Materials and methods}

\section{Soil and biochar}

Topsoil (from 0 to $20 \mathrm{~cm}$ of depth) was collected from an agricultural field in the Foggia district (Apulia Region, southern Italy). Before the experiments started, a soil physicochemical characterisation was carried out. The particle-size distribution was determined using the pipette-gravimetric method. The water holding capacities at $-0.03 \mathrm{MPa}$ (field capacity) and $-1.5 \mathrm{MPa}$ (wilting point) were obtained using a pressure-plate apparatus (Soilmoisture Equipment Corp.). The $\mathrm{pH}$ and electrical conductivity were measured on 1:2.5 (w/v) aqueous soil extracts and saturated soil paste extracts, by a GLP 22+ pH-meter and a GLP 31+ EC-meter (Crison Instruments, Barcelona), respectively. The available phosphorus was determined by the sodium bicarbonate method (Olsen et al., 1954), and the total organic carbon by the Walkley-Black (1934) acid dichromate digestion technique. The total nitrogen was obtained according to the Kjeldahl method (Bremner 1996) and the $\mathrm{NO}_{3}{ }^{-}-\mathrm{N}$ content was determined by soil extraction with 2 $\mathrm{M} \mathrm{KCl}$, followed by spectrophotometric analysis of the extract (Keeney and Nelson, 1982). Soil had a silty clay loam texture (United States Department of Agriculture classification), with a field capacity of $38.0 \%$ dry weight (dw), a wilting point of $20.3 \% \mathrm{dw}$. The main characteristics were: clay, 27.6\%; silt, $55.8 \%$; sand, $16.6 \%$; organic matter, $0.4 \%$; total nitrogen, $0.4 \%$; $\mathrm{NO}_{3}{ }^{-}-\mathrm{N}, 2.6 \mathrm{mg} \mathrm{N} \mathrm{kg}{ }^{-1} ; \mathrm{P}_{2} \mathrm{O}_{5}, 41.8 \mathrm{ppm} ; \mathrm{pH} 8.4$; and electrical conductivity, $0.3 \mathrm{dS} \mathrm{m} \mathrm{m}^{-1}$.

Biochar was purchased from a commercial producer. It was obtained by pyrogasification of fire wood chips. Biomass pyrogasification occurred at temperature up to $1200^{\circ} \mathrm{C}$ in a gasifier unit rated at $200 \mathrm{kWe}$ in delivered power capacity. A set of chemical analyses was conducted on biochar. Proximate analysis determined the relative content in total solid (TS), volatile solid (VS), ash (AS) and fixed carbon (FC), using a TGA analyser unit (LECO-TGA701), according to the ASTM D7582 method. pH and electrical conductivity were determined using a biochar to deionised water mass ratio 1:20, followed by shaking and waiting an equilibrium time of 5 min before measurement by a GLP 22+ pH-meter and a GLP 31+ EC-meter (Crison Instruments, Barcelona), respectively. Ultimate analysis determined the $\mathrm{C}, \mathrm{N}, \mathrm{H}$ and S content using a CHNS Elemental Analyser (CHN LECO 680), according to the method LECO-ASTM D5373. 0 content was calculated by the difference: oxygen (0) (\%) = 100-C-H-N-S-ash. From hydrogen $(\mathrm{H})$, carbon (C) and 0 content, the molar ratios of hydrogen to organic carbon $\left(\mathrm{H} / \mathrm{C}_{\text {org }}\right)$ and oxygen to organic carbon $\left(0 / \mathrm{C}_{\text {org }}\right)$ were obtained. Micro- and macro-elements analysis was performed by digesting $0.25 \mathrm{~g}$ of sample in $10 \mathrm{~mL}$ of $\mathrm{HNO}_{3}$ in a closed vessel microwave digester (CEM-Mars6) for $20 \mathrm{~min}$ at $220^{\circ} \mathrm{C}$. The metals in the solution were analysed by inductively coupling plasma spectrometry-optical emission spectroscopy (ICP-OES Agilent 720). Biochar was alkaline with a pH of 9.4 and showed a salinity level of $300 \mathrm{mSm}^{-1}$. Proximate analysis indicated that biochar contained $88.0 \%$ FC, $8.7 \%$ VS and 3.3\% AS. Ultimate analysis showed that biochar was carbonrich, with a $\mathrm{C}$ content of $83.2 \%$ by mass, and $1.7 \% \mathrm{H}, 0.4 \%$ nitrogen (N), $0.05 \%$ sulphur (S) and $11.4 \% 0$ by mass. $\mathrm{H} / \mathrm{C}_{\text {org }}$ and $0 / \mathrm{C}_{\text {org }}$ were equal to 0.25 and 0.10 , respectively (lower values of these ratios are correlated with greater carbon stability). ICP-OES analysis revealed the presence of inorganic nutrients such as potassium (K) (25244.8 mg kg-1), calcium (Ca) (4392.5 mg kg-1), magnesium (Mg) (1043.5 $\mathrm{mg} \mathrm{kg}-1$ ) and iron (Fe) (1023.6 mg kg-1). Heavy metals concentrations ranged from not detectable amount for cadmium (Cd), copper (Co) and lead $(\mathrm{Pb})$ to amounts as high as $286.6 \mathrm{mg} \mathrm{kg}^{-1}$ for manganese $(\mathrm{Mn})$. According to the technical specifications published by the Italian Ministry of Agriculture which has recently approved the inclusion of biochar in the list of soil amendments allowed in Italian agriculture (Italian Official Journal - General Series No 186, 12-82015), biochar is assigned to a class on the basis of its percentage content of organic $\mathrm{C}$ and ash. Biochar used in our experiments belonged to the Class $1\left(\mathrm{C}_{\text {org }}>60 \%\right.$; ash $\left.<10 \%\right)$. Moreover, all the requirements of the Italian technical specifications (salinity $\leq 1000$ $\mathrm{mSm}^{-1}, \mathrm{pH}=4-12, \mathrm{H}_{\mathrm{C}} \mathrm{org} \leq 0.7$ ) were fully complied.

Before laboratory experiments started, subsamples of air-dried soil were respectively added and homogeneously mixed with subsamples of air-dried biochar. Biochar and soil were preliminary sieved at $1 \mathrm{~mm}$ in order to increase the area:volume ratio of the respective particles thus maximising their reciprocal interaction. Biochar was applied at rates of 2,4 and $8 \%$ of dry soil weight. Rates of biochar application could be considered equivalent to 48, 96 and $192 \mathrm{Mg} \mathrm{ha}^{-1}$, assuming a soil bulk density of $1.2 \mathrm{Mg} \mathrm{m}^{-3}$ and a soil depth of $0.20 \mathrm{~m}$. The obtained mixtures were maintained at room temperature $\left(22 \pm 0.5^{\circ} \mathrm{C}\right)$ until their utilisation.

\section{Nitrate sorption experiments}

A range of laboratory experiments was performed comparing four soil treatments: soil only (control, B0); soil $+2 \%$ biochar (g biochar per g soil, B2); soil + 4\% biochar (B4); soil + 8\% biochar (B8). A stock solution of $5 \mathrm{mg} \mathrm{NO}{ }_{3}^{-} \mathrm{L}^{-1}$ was prepared by dissolving $8.20 \mathrm{~g}$ of $\mathrm{KNO}_{3}$ in $1 \mathrm{~L}$ of deionised water and serial dilutions were applied to obtain concentrations of $5,10,50,100,200,300$ e $400 \mathrm{mg} \mathrm{NO}_{3}{ }^{-} \mathrm{L}^{-1}$. At room temperature $\left(22 \pm 0.5^{\circ} \mathrm{C}\right)$ and for each soil treatment, $100 \mathrm{mg}$ of soil was added into a vessel and mixed with $50 \mathrm{~mL}$ of each nitrate solution. The mixtures were stirred for $24 \mathrm{~h}$ with a mechanical shaker. After reaching equilibrium, the soil-biochar suspensions were filtered with a $0.22 \mu \mathrm{m}$ nylon membrane filter. The filtrate $\mathrm{NO}_{3}{ }^{-}$concentration at equilibrium was then analysed by ion-exchange chromatography (Dionex ICS-1100, Dionex Corp., Sunnyvale, CA, USA). All the experiments were carried out in duplicate.

For each sample, sorbed nitrate was calculated by applying the following equation:

$Q_{\mathrm{e}}=(\mathrm{V} / \mathrm{W}) *\left(\mathrm{C}_{\mathrm{i}}-\mathrm{C}_{\mathrm{e}}\right)$

where: $Q_{\mathrm{e}}=$ amount of $\mathrm{NO}_{3}{ }^{-}$adsorbed per unit weight of sample at equilibrium ( $\left.\mathrm{mg} \mathrm{g}^{-1}\right) ; \mathrm{V}=$ volume of the liquid phase $(\mathrm{mL}) ; \mathrm{W}=$ soil sample weight (mg); $\mathrm{C}_{\mathrm{i}}$ e $\mathrm{C}_{\mathrm{e}}=$ initial and final (at equilibrium) concentrations of $\mathrm{NO}_{3}{ }^{-}$in the liquid phase $\left(\mathrm{mg} \mathrm{L}^{-1}\right)$.

To describe the empirical relationship between the amount of adsorbed and dissolved $\mathrm{NO}_{3}{ }^{-}$, considering the soil-biochar mixtures at equilibrium and constant temperature, the Freundlich sorption model was applied as follow:

$Q_{\mathrm{e}}=\mathrm{K}_{\mathrm{f}} * \mathrm{C}_{\mathrm{e}}{ }^{1 / \mathrm{n}}$

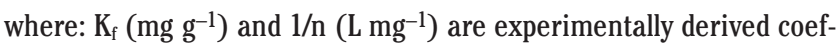
ficients specifically related to the sorbent-sorbate system. $K_{f}$ stands for the initial adsorption capacity, while $1 / n$ corresponds to the sorption intensity. The higher $\mathrm{K}_{\mathrm{f}}$, the greater the adsorption capacity; the higher $1 / n$, the higher the sorption intensity; if $n=1$, then sorption is linear. The values of these empirical coefficients were obtained from the linearised form of the Freundlich model: 
$\log Q_{e}=\log K_{f}+1 / n \log C_{e}$

where: $\log K_{f}$ is the intercept while $1 / n$ is the slope of the regression line.

The log-transformed data set was processed as a whole by applying an analysis of co-variance (ANCOVA), i.e., a general linear model which processes together levels of a categorical independent variable (the soil-biochar treatments) with a continuous variable, known as covariate or regressor (the $\mathrm{C}_{\mathrm{e}}$ liquid phase concentrations). According to this procedure, a statistical discrimination among the values of intercepts and slopes of the regression lines becomes viable.

\section{Results and discussion}

Figure 1 shows the $\mathrm{NO}_{3}{ }^{-}$sorption isotherms of the four soil treatments according to the linear form of the Freundlich model, resulting from the ANCOVA statistical procedure and obtained by plotting log Qe against $\log$ Ce. Nitrate retention in the soil mixed with biochar was always higher than the control, regardless the $\mathrm{NO}_{3}{ }^{-}$concentration in the range of $0-400 \mathrm{mg} \mathrm{L}^{-1}$. Different sorption capacities and intensities were detected depending on the biochar application rate. Indeed, as resulting from the values of intercepts and slopes of the linear Freundlich model reported in Table 1, soil treatments B2 and B4 were not statistically different each other, while B8 showed different $K_{f}$ and $1 / n$ values in respect to both B2 and B4 as well as compared to $\mathrm{B} 0$. In particular, the nitrate sorption capacity (the $\mathrm{K}_{\mathrm{f}}$ intercept value) for B2 and B4 resulted significantly higher than the other two soil treatments, highlighting the enhanced $\mathrm{NO}_{3}{ }^{-}$adsorption capacity of the soil when treated with 2 and $4 \%$ of biochar by mass. Conversely, the intensity of nitrate retention (the $1 / \mathrm{n}$ slope value) in the soil without biochar addition (B0) was significantly higher than in the soil-biochar mixes (B2, B4 and B8). By observing Figure 1 is easy to note that the four lines tend to converge at higher nitrate equilibrium values. From the results obtained is possible to reasonable infer that nitrate retention is higher at lower biochar addition rate to soil (B2 and B4) and at lower nitrate concentration in the soil water solution.

A straightforward explanation for the effect of biochar on nutrient retention is that it acts as an adsorbent (Clough et al., 2013). Organic material generally has some adsorption capacity and the charring process, especially at higher temperatures, usually increases this feature (Bhatnagar and Sillanpaa, 2010). The nitrate retention observed in the soil-biochar mixtures might indicate $\mathrm{a} \mathrm{NO}_{3}{ }^{-}$adsorption process due to the high temperature at which biochar was obtained. As observed by Cheng et al. (2008), biochars produced at high temperatures have a greater specific surface area and are positively charged. Kameyama et al. (2012) reported that $\mathrm{NO}_{3}{ }^{-}$sorption to biochar increased with greater biochar production temperatures, due to the formation of basic functional groups. The findings of this study are consistent with the results of other biochar researches carried out under controlled laboratory-based conditions (Mizuta et al., 2004; Yao et al., 2012; Liang et al., 2014), which observed some nitrate adsorption with some high temperature biochars. They are also in line with the results of a field experiment recently reported by Haider et al. (2016). The authors observed that on a cultivated temperate sandy soil biochar reduced nitrate leaching. $\mathrm{NO}_{3}{ }^{-}$sorption in biochar amended soil was attributed to several mechanisms, such as solution mass flow into biochar particles, where the $\mathrm{NO}_{3}{ }^{-}$ions are physically entrapped within biochar pores; non conventional $\mathrm{H}$ bonding and bonding between $\mathrm{NO}_{3}{ }^{-}$and functional groups or positively charged cations on biochar surface.

\section{Conclusions}

Based on a preliminary laboratory assessment, the obtained results showed the positive effect of biochar on soil nitrate retention. The addition of a biochar from fir wood to a silty clay loam soil, particularly at the rate of 2 and $4 \%$, enhanced the soil $\mathrm{NO}_{3}{ }^{-}$sorption. The present findings will be extend to long-term experimental trials under field conditions in order to fully investigate the effects of biochar characteristics and soil properties interactions on nitrate retention. Elucidating these aspects may enable the optimisation of large-scale application of biochar to agricultural fields as an effective option of nitrate leaching mitigation.

Table 1. Analysis of co-variance results. Coefficients of the linearised Freundlich sorption model as applied to nitrate for the four experimental soil-biochar mixtures $\left(\mathrm{B}_{\mathrm{i}}\right)$. The reported $\Delta$ values are the incremental effects due to soil treatments with respect to the average values of the intercept $\left(\log K_{f}\right)$ and slope $(1 / n)$, respectively.

\begin{tabular}{|c|c|c|c|c|}
\hline Term & Estimate & * & Standard erro & $\mathbf{P}$ \\
\hline Intercept - $\log \mathrm{Kf}$ & -0.48 & & 0.06 & $<0.0001$ \\
\hline$\Delta \mathrm{B} 2$ & +0.46 & $\mathrm{a}$ & 0.11 & $<0.0001$ \\
\hline$\Delta \mathrm{B} 4$ & +0.29 & $\mathrm{a}$ & 0.11 & 0.0095 \\
\hline$\Delta \mathrm{B} 8$ & -0.16 & b & 0.11 & 0.1791 \\
\hline$\Delta \mathrm{B} 0$ & -0.60 & c & 0.12 & $<0.0001$ \\
\hline Slope - $1 / n$ & 1.02 & & 0.04 & $<0.0001$ \\
\hline$\Delta \mathrm{B} 2$ & -0.12 & $\mathrm{a}$ & 0.06 & 0.0625 \\
\hline$\Delta \mathrm{B} 4$ & -0.10 & $\mathrm{a}$ & 0.06 & 0.1389 \\
\hline$\Delta \mathrm{B} 8$ & +0.04 & $\mathrm{~b}$ & 0.07 & 0.5582 \\
\hline$\Delta \mathrm{B} 0$ & +0.18 & c & 0.07 & 0.0129 \\
\hline $\mathrm{R}^{2}$ & - & & \multicolumn{2}{|c|}{0.94} \\
\hline RMSE & - & & \multicolumn{2}{|c|}{0.19} \\
\hline CV (\%) & - & & \multicolumn{2}{|c|}{16.16} \\
\hline
\end{tabular}

*Values followed by the same letters are not significantly different $(\mathrm{P} \leq 0.05)$. RMSE, root mean square error; CV, cultivar.

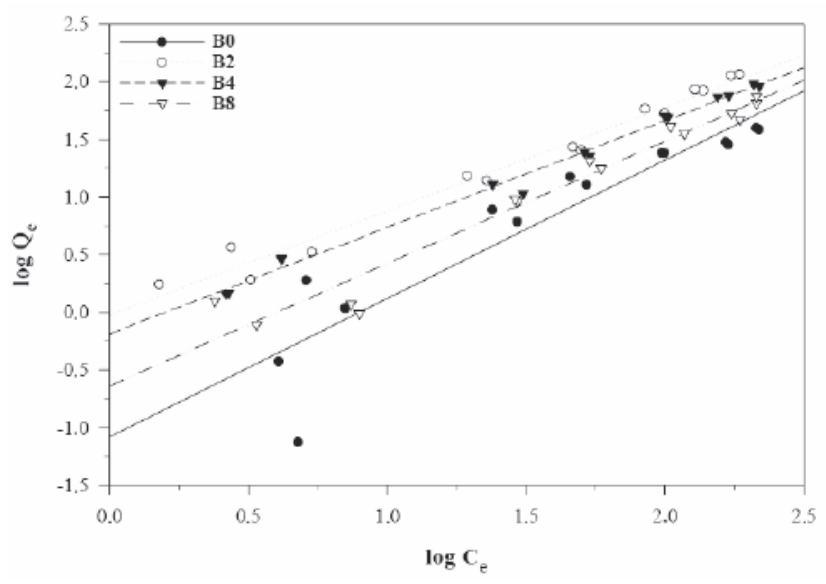

Figure 1. Linearised sorption isotherms according to the Freundlich model as applied to nitrate for the four experimental soil-biochar mixtures. 


\section{References}

Atkinson CJ, Fitzgerald, JD, Hipps NA, 2010. Potential mechanisms for achieving agricultural benefits from biochar application to temperate soils: a review. Plant Soil 337:1-18.

Bhatnagar A, Sillanpaa M, 2010. Utilisation of agro-industrial and municipal waste materials as potential adsorbents for water treatment: a review. Chem. Eng. J. 157:277-96.

Bradley A, Larson RA, Runge T, 2015. Effect of wood biochar in manureapplied sand columns on leachate quality. J. Environ. Qual. 44:1720-8.

Bremner JM, 1996. Nitrogen-total. In: D.L. Sparks, A.L. Page, C.T. Johnston, M.E. Summ (Eds.), Methods of soil analysis Part 3. Chemical methods. SSSA Book Ser. No. 5. SSSA, Madison, Wi, USA, pp 1058-1121.

Buecker J, Kloss S, Wimmer B, Rempt F, Zehetner F, Soja G, 2016. Leachate Composition of Temperate Agricultural Soils in Response to Biochar Application. Water Air Soil Poll. 227:49.

Cheng CH, Lehmann J, Engelhard MH, 2008. Natural oxidation of black carbon in soils: changes in molecular form and surface charge along a climosequence. Geochim. Cosmochim. Acta 72:1598-610.

Clough TJ, Condron LM, Kamman C, Muller C, 2013. A review of biochar and soil nitrogen dynamics. Agronomy 3:275-93.

Eykelbosh AJ, Johnson MS, Guimarães Couto E, 2015. Biochar decreases dissolved organic carbon but not nitrate leaching in relation to vinasse application in a Brazilian sugarcane soil. J. Environ. Manage. 149:9-16.

Gul S, Whalen JK, Thomas BW, Sachdeva V, Deng H, 2015. Physicochemical properties and microbial responses in biochar-amended soils: mechanisms and future directions. Agr. Ecosyst. Environ. 206:46-59.

Haider G, Steffens D, Müller C, Kammann CI, 2016. Standard extraction methods may under stimate nitrate stocks captured by field-aged biochar. J. Environ. Qual. 45:1196-204.

Hollister CC, Bisogni JJ, Lehmann J, 2013. Ammonium, nitrate, and phosphate sorption to and solute leaching from biochars prepared from corn stover (Zea mays L.) and oak wood (Quercus spp.). J. Environ. Qual. 42:137-44.

Kameyama K, Miyamoto T, Shiono T, Shinogi Y, 2012. Influence of sugarcane bagasse-derived biochar application on nitrate leaching in calcaric dark red soil. J. Environ. Qual. 41:1131-7.
Kanthle AK, Lenka NK, Lenka S, Tedia K, 2016. Biochar impact on nitrate leaching as influenced by native soil organic carbon in an Inceptisol of central India. Soil Till. Res. 157:65-72.

Keeney DR, Nelson DW, 1982. Nitrogen inorganic forms. In: Methods of soil analysis. Part 2, 2nd ed. Agron. Monogr. 9 ASA and SSSA. Madison, WI, USA, pp 643-698.

Knowles OA, Robinson BH, Contangelo A, Clucas L, 2011. Biochar for the mitigation of nitrate leaching from soil amended with biosolids. Sci. Total Environ. 409:3206-10.

Laird DA, 2008. The Charcoal Vision: a win-win-win scenario for simultaneously producing bioenergy, permanently sequestering carbon, while improving soil and water quality. Agron. J. 100:178-81.

Laird DA, Brown RC, Amonette JE, Lehmann J, 2009. Review of the pyrolysis platform for co-producing bio-oil and biochar. Biofuels Bioprod. Bior. 3:547-62.

Liang X, Ji YJ, He MM, Su MM, Liu CL, Tian GM, 2014. Simple N balance assessment for optimising the biochar amendment level in paddy soils. Commun. Soil Sci. Plan. 45:1247-58.

Lone AH, Najar GR, Ganie MA, Sofi JA, Ali T, 2015. Biochar for sustainable soil health: a review of prospects and concerns. Pedosphere 25:639-53.

Mizuta K, Matsumoto T, Hatate Y, Nishihara K, Nakanishi T, 2004. Removal of nitrate-nitrogen from Drink-B. Foereid 43 in water using bamboo powder charcoal. Bioresource Technol. 95:255-7.

Olsen SR, Cole CV, Watanabe FS, Dean LA, 1954. Estimation of available phosphorus in soil by extraction with sodium bicarbonate. USDA Circular 939, Washington, DC, USA, pp 1-19.

Vaccari F, Baronti S, Lugato E, Genesio L, Castaldi S, Fornasier F, Miglietta F, 2011. Biochar as a strategy to sequester carbon and increase yield in durum wheat. Eur. J. Agron. 34:231-8.

Ventura M, Sorrenti G, Panzacchi P, George E, Tonon G, 2013. Biochar reduces short-term nitrate leaching from a horizon in an apple orchard. J. Environ. Qual. 42:76-82.

Walkley A, Black IA, 1934. An examination of the Degtjareff method for determining soil organic matter and a proposed modification of the chromic acid titration method. Soil Sci. 37:29-38.

Yao Y, Gao B, Zhang M, Inyang M, Zimmerman AR, 2012. Effect of biochar amendment on sorption and leaching of nitrate, ammonium, and phosphate in a sandy soil. Chemosphere 89:1467-71.

Yuan H, Lu T, Wang Y, Chen Y, Lei T, 2016. Sewage sludge biochar: nutrient composition and its effect on the leaching of soil nutrients. Geoderma 267:17-23. 